Estudos de Economia, vol. III, n.², Jan.-Mar., 1983

\title{
SURPLUS LABOUR AS A SOURCE OF FOREIGN EXCHANGE?
}

\author{
Martin Godfrey
}

\section{The surplus labour debate}

The discussion of surplus labour in the development economics literature of the fifties and sixties was essentially optimistic (1). Surplus labour was seen as a potential resource which, directly or indirectly, assisted capital accumulation.

Its direct role was emphasised by Nurkse, who drew attention (Nurkse, 1953) to the saving potencial concealed in rural underemployment. Workers of zero marginal productivity can, by definition, be removed from the land without affecting output. Thus presumably they could work on capital projects while continuing to depend for their subsistence on the productive peasants remaining on the farms. None would be eating less than before but all would now be productively employed. Such a programme of mobilisation of the hidden saving potential might include community development projects specially designed to make use of local labour surpluses or of seasonal slack periods in the countryside or might involve the temporary or permanent geographical transfer of labour to work on social overhead capital projects.

Lewis, on the other hand, had in mind an indirect role for surplus labour in the subsistence sector - that of allowing accumulation and growth in the capitalist sector (Lewis, 1954). His subsistence sector, where the surplus labour of "negligible zero or even negative" marginal product is to be found, consists not only of agriculture but also of petty retail trading, domestic service and "the whole range of casual jobs - the workers on the docks, the young men who rush forward asking to carry your bag as you appear, the jobbing gardener, and the like"... - in fact "all that part of the economy which is not using reproducible capital». In the other, capitalist sector the profit maximisation calculus applies and labourers are only employed up to the point where their marginal product is equal to their wage. The minimum wage that the capitalist sector has to pay to labour is set by the average product in the subsistence sector (plus a constant margin) and since the transfer of labour can take place without affecting output in the subsistence sector it has no effect on the price 
of wage-goods produced by the subsistence sector. Thus an unlimited supply of labour is available when needed by the capitalist sector at a constant real wage. The resulting surplus is reinvested by profit-earners, and growth and reinvestment become a continuous process.

These optimistic visions could not be sustained into the late sixties and seventies. The Nurksean programme foundered on the difficulties of achieving the necessary social and political reorganisation and of preventing leakages in the subsistence fund available for capital formation through increased consumption by the remaining peasants and/or by the new investment workers. The preoccupation of the Lewis model with accumulation and growth was overshadowed by the growing evidence that the subsistence sector was releasing labour at a rate far in excess of the rate at which the capitalist sector could absorb it. So, within development economics, from the optimism of the surplus labour analysis the pendulum swung to the pessimism of the "employment problem", with the emphasis particularly on urban unemployment.

In the Marxian literature, similarly, those who felt that Marx's concept of industrial reserve army and his emphasis on its functionality to accumulation, although based on the experience of mature capitalism, were still more or less adequate to explain the role of surplus population at the periphery under monopoly capitalism where challenged by the "marginalisation" branch of the dependency school. These writers define the marginalised labour force or "marginal mass" as surplus population over and above what is necessary to perfom the functions of the industrial reserve army $i$. e. as non-functional surplus population. Analysis in these terms is profoundly pessimistic, not merely questioning the employment-generating performance of peripheral capitalism but also denying its capacity to perform its historically progressive Marxian role.

In the context of the discussion of both of these strands of analysis of surplus labour - development economics and the Marxian - the emergence of the concept of the informal sector during the seventies represented a reaffirmation of optimism. However, on closer inspection faith in the dynamic potential of the sector (which would be fully released if only government policy towards it were to become friendly rather than hostile) and in its contribution to accumulation via the spread of capitalist relations of production has proved difficult to sustain.

\section{Surplus labour and internationalised production}

Most of the discussion of surplus labour, whether in the development-economics or Marxian tradition, has tended to concentrate on the closed economy. However, Lewis had a section on the open economy in his 1954 paper in which he briefly explored the implications of migration from labour-surplus to labour-shortage economies and of movement of capital in the opposite direction. 
Since Lewis wrote, the internationalisation of production has increased considerably, and integration into the international labour market in either or both of these ways has come to be seen by many surplus-labour economies as a possible escape route from the misery predicted by the pessimistic analysis summarised above. The main purpose of this paper is to consider the realism of these hopes. How far can such economies as the Philippines, Bangladesh, Egypt and Sri Lanka, by exporting unskilled workers and/or by importing capital to employ unskilled workers in industries producing for the world market, use their surplus labour as a source of foreign exchange and as a springboard into self-sustaining development?

At the time when Lewis was writing industry producing for the world market was located only in the labour-shortage economies of the North. Production in the South for the world market consisted only of primary products (inputs for Northern industry and wage-goods for Northern workers). In addition the capitalist sector included a certain amount of import-substituting industry, producing for a protected domestic market. Migration of labour from South to North was negligible. Thus the huge reserve of surplus labour in the South was only indirectly relevant to Northern capitalists, through its effect on input and wage-good prices. Figure 1 illustrates the situation with the usual two-sector diagrams $\left({ }^{2}\right)$.

FIGURE 1

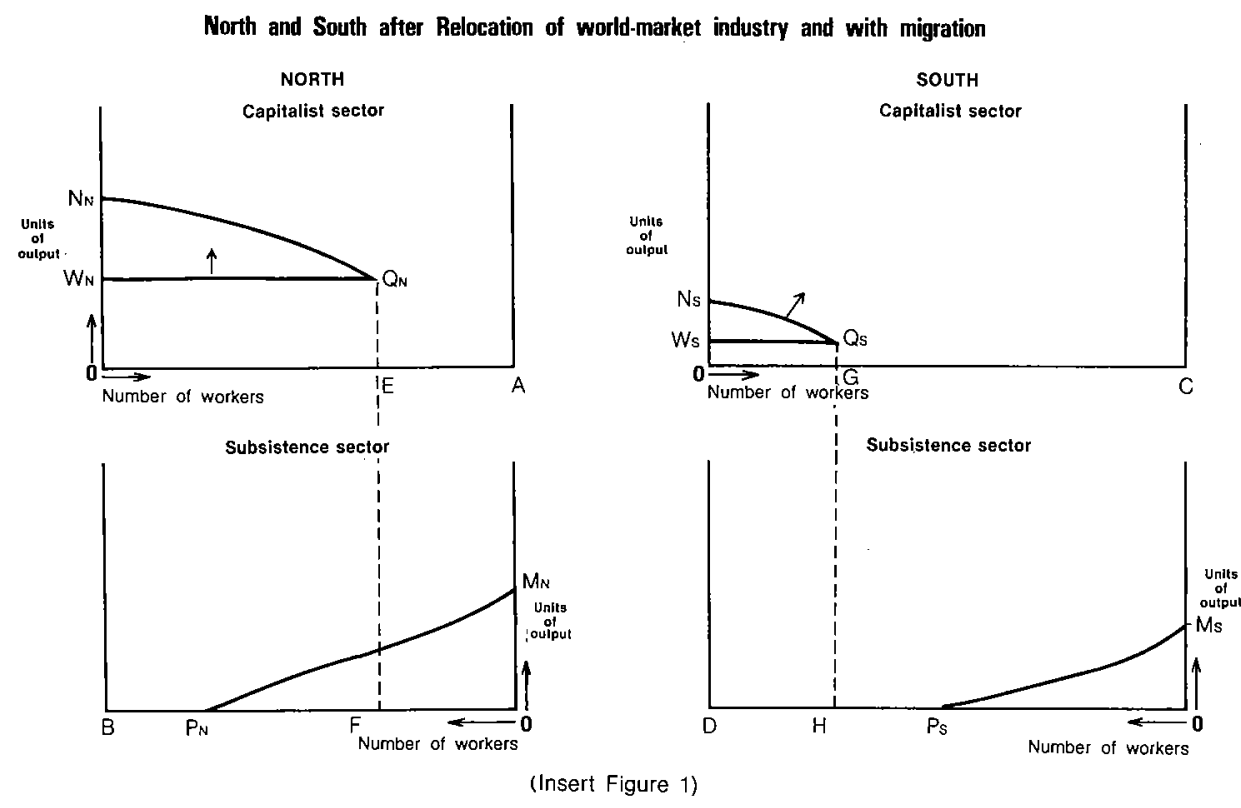

(2) Based on Ranis and Fei (1962). Comparative-static, ceteris paribus diagrams of this kind clearly do not tell the full story. They abstract from several important phenomena, such as population growth, and the eventual outcomes depend on a number of second-and-later-stage effects and more or less exogenous events. Figure 3 attempts to trace some of these through. 
The curves $N_{N}$ and $Q_{N}$ and $N_{S}$ and $Q_{S}$ show the demand for labour in the capitalist sectors of the North and South respectively. The curves $M_{N} P_{N}$ and $M_{S} P_{S}$ show the marginal productivity of workers in the subsistence sectors of the North and South respectively. (The position of the origin in the subsistence sector diagrams should be noted.) In the North there is no surplus labour in the subsistence sector; at the wage $\mathrm{OW}_{\mathrm{N}} \mathrm{OE}$ workers are employed in the capitalist sector (derived in the usual Lewis-model way) leaving OF workers in the subsistence sector. If productivity rises in the capitalist sector, wages will rise also. In the South, on the other hand, there is Ps surplus labour in the subsistence sector and until that surplus is absorbed unlimited labour is available to the capitalist sector at the wage $O \mathrm{~W}_{\mathrm{s}}\left({ }^{3}\right)$. Thus, if productivity were to rise in the capitalist primary production sector, signified by an outward shift in $N_{s} Q_{s}$ this would not affect wages in that sector, which would remain at $\mathrm{OW}_{\mathrm{s}}$.

However, the resulting fall in prices of the primary products would benefit workers and capitalists in the Northern capitalist sector, since the exchange value of a given unit of the sector's output would increase ( $\left.{ }^{4}\right)$.

As soon as industrial production for the world market began to be located in the South as well as the North, and South-North migration became significant, the reserve of surplus labour in the South became, potentialy, directly as well as indirectly relevant to the North. Capitalists in economies running into labour shortage could escape its consequences either by employing immigrant labour or by exporting capital to labour-surplus economies. Both of these processes would result, ceteris paribus, if not in convergence of wage rates in the two sets of countries, at least in moderation of the rate of divergence. Figure 2 illustrates the effect of these changes on our two-sector diagrams (by means of the dotted-line curves).

The effect of migration is shown by the shift inwards of the origin and the marginal-productivity-of-workers curve in the Southern subsistence sector and a commensurate shift outwards in its Northern counterpart. As drawn, the labour surplus in the South is reduced and the labour shortage in the North substantially eased. In general, the wage in the Southern capitalist sector would tend to rise and that in the North to fall, with the extent depending on the scale of these movements. As Lewis points out (p. 436), «if there were free immigration from India and China to the USA, the wage level of the USA would certainly be pulled down towards Indian and Chinese levels". If, on the other hand, "100,000 Puerto Ricans emigrate to the United States every year, the effect on US wages is negligible; it is Puerto Rican wages which are then pulled up to the US leveln.

(3) Strictly speaking, to preserve the assumption of an unlimited supply of labour to the capitalist sector at a constant real wage it is necessary to assume one or more of the following: that the tie between average product in the subsistence sector and the capitalist wage is not absolutely rigid; that the labour force is not given; or that the state or a landlord class extracts the agricultural surplus and holds down rural.

(4) Cf. Prebisch, Singer, Emmanuel, Amin. 
The extent of the impact of migration on wages would also depend on the nature of the relevant labour markets. For instance Doeringer and Piore have suggested that the United States labour force is divided into two sectors, primary and secondary, with distinct characteristics. "The primary market offers jobs which possess several of the following traits: high wages, good working conditions, employment stability and job security, equity and due process in the administration of work rules, and chances for advancement. The secondary market has jobs which, relative to those in the primary sector, are decidedly less attractive. They tend to involve low wages, poor working conditions, considerable variability in employment, harsh and often arbitrary discipline, and little opportunity to advancen (Piore, 1971). The two sectors constitute non-competing groups, with very little movement from one to the other. If this analysis is generally applicable to Northern economies and if unskilled immigrants (along with women, ethnic minorities and the disadvantaged) join the secondary market this will limit the impact of immigration on primary-market wages although it may still affect the average wage level in the capitalist sector as a whole.

FIGURE 2

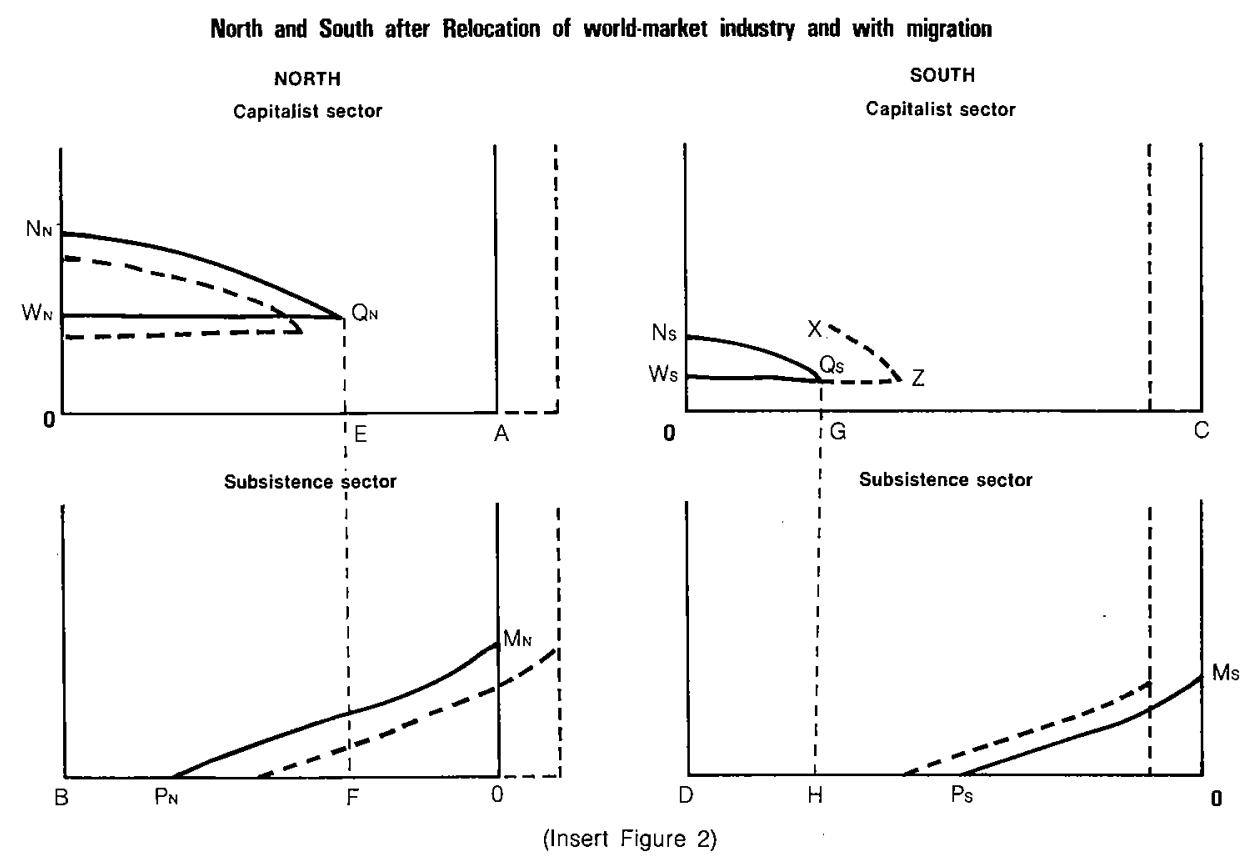

As for export of capital to world market factories, this would reduce wages in the capital-exporting countries because it reduces the demand for labour directly by cutting capital accumulation at home and indirectly by raising productivity and lowering prices in competing industries abroad - a particular Northern economy may find itself facing such competition from a particular Southern economy not only in third markets but also in its own home market. These effects are shown in Figure 2 by the inward and downward shifts of 
$N_{N} Q_{N}$ and $W_{N} Q_{N}$. This might be offset to some extent by the cheapening of some manufactured goods exported to the North from these new Southern factories.

Demand for labour in the capital-importing economies would increase (as shown by the new sector's demand curve $X Z$ ) but whether or not this affected wages there would depend on whether it was large enough to shift them from a labour-surplus to a labour-shortage situation.

What has happened might be characterised, in Marxian terms, as at least the first small steps towards the "internationalisation of the reserve army". Marx saw the reserve army as functioning in two ways: literally as a reserve, ready for action in expansionary phases of the cycle and to be expelled in recessionary phases; and as enforcing the discipline of the labour market, ensuring that wages did not rise above the long-run supply-price of labour. The international reserve army seems already to be functioning in the first sense, through the relocation of jobs and the use of imigrant labour. We have seen that it is at least potentially important in the second sense though whether in fact it has moderated the rate of divergence of wages between North and South is an empirical question which remains to be answered (5).

\section{Exporting workers}

The analysis pursued so far, while, it is to be hoped, useful to an attempt to characterise the processes, is too aggregated to be particularly helpful to economies contemplating the use of their surplus labour as a source of foreign exchange. The more detailed issues involved will now be briefly explored further, starting with the strategy of exporting workers.

The number of people from developing countries working outside their own countries towards the end of the 1970s is estimated at around $20 \mathrm{mn}$. Of these some $6 \mathrm{mn}$ were in the USA (mainly from Mexico) (Piore, 1979), $5 \mathrm{mn}$ in Western Europe (mainly from Yugoslavia, Greece, Portugal, Spain, Turkey, Italy, Morocco, Tunisia and Algeria) (Paine, 1974; Böhning, 1979), and $3 \mathrm{mn}$ in the Arab region, particularly Saudi Arabia, Kuwait, Qatar, United Arab Emirates and Libya (mainly from Egypt, Jordan, Yemen A. R., Yemen P. D. R., the Sudan, Syria, India, Pakistan, South Korea, Taiwan and Bangladesh) (Birks and Sinclair, 1979). In addition there are longstanding migration systems in Southern Africa (to South Africa, from Lesotho, Botswana, Swaziland, Mozambique and until recently Malawi) and Western Africa (to Ivory Coast from Upper Volta, Mali, Benin and Guinea) (Amin, 1979).

(5) This is not to suggest that the international reserve army is uniquely functional to Northern capital which has other options open to it. See Paine (1974) for a criticism of "crude» reserve army theorists. 
Perhaps the most interesting destination from the point of view of this paper, and the one which fits most closely the "reserve army" characterisation, is Western Europe. The number of migrants in its labour force rose from. $2 \mathrm{mn}$ in the early sixties to over $6 \mathrm{mn}$ in the early seventies and then declined with the onset of the recession. However, the seventies also saw a huge increase in migration to the oil-producing countries of the Arab region $\left.{ }^{6}\right)$ which more than offset this decline.

By definition, as Figure 1 illustrates, the export of surplus labour should have no effect on output in the labour-losing economy, but matters are rarely as simples as that. The proportion of totally unskilled migrants may be smaller than expected; for instance, $62 \%$ of foreign workers entering France between 1964 and 1968 were classified as skilled or semiskilled (Ecevit and Zachariah, 1978) and the comparable figure for Saudi Arabia in 1975 was $46 \%$ (op. cit.). Even when unskilled a high proportion of migrants may be young males with key roles in the division of labour within the village economy; considerable reorganisation of work may be necessary to avoid a fall in output as a consequence of emigration. Thus the immediate costs of exporting workers may be higher than expected.

The benefits of the strategy would be expected to come in two further stages, first through remittances and, later, returned migrants. The scale of emigrants' remittances as a source of foreign exchange has increased enormously over the past decade.

By the end of the seventies recorded remittances alone were estimated at around $\$ 24,000 \mathrm{mn}$, compared with less than $\$ 3,000 \mathrm{mn}$ ten years earlier. For individual labour-exporting countries the returns can be dazzling. For example, Yugoslavia alone received $\$ 1,728 \mathrm{mn}$ from this source in 1976, equivalent to $22 \%$ of its import bill. Yugoslavia is a relatively high-income country and at that time there were over 696,000 Yugosiavs working in Europe, equivalent to $16 \%$ of those working in Yugoslavia. Lower-income labour-surplus economies such as Bangladesh can finance an even higher proportion of their foreign exchange obligations in this way from a much smaller proportion of their labour force. For instance, the 200,000 Bangladeshis working abroad in 1978/79 represented less than one per cent of the labour force but their remittances of $\$ 180 \mathrm{mn}$ were equivalent to around $40 \%$ of the commercial import bill (Mahmood 1981).

Again, however, all is not plain sailing. As migrants «mature» (Böhning 1972), lengthen their stay and are joined by their dependents, their propensity to remit tends to fall. Moreover in market economies remittances can hardly be regarded as net additions to foreign exchange earnings available for socially optimal uses. Much is in the form of consumer goods rather than money; money remittances tend to be spent predominantly on consumer goods (usally with a high import

(6) The capital-surplus Arab countries do not fit neatly into our North-South diagrams. It is probably most convenient for this purpose only to exclude them from both North and South. 
content), housing, land and schooling. Clearly the lucky recipients benefit, but indirect effects may be negative. Appreciation of the exchange rate may affect the competitiveness of manufactured exports and the profitability of primary products. Land and other prices may rise and the demonstration effect of remittances may be strong. In areas where a high proportion of the labour force is abroad this may come to be seen as the only route to higher incomes and spectacular consumption patterns, with a debilitating effect on the local economy.

Returned migrants might be expected to be an important source of skills to galvanise the rural and industrial economies to which they return. The extent to which this happens varies widely but in general experience has been disappointing. For instance, Piore (1979) reports of migrants into the United States that they "have not been a significant source of industrial skills" for their home economies. "The most skilled of the migrant workers are reluctant to return home. Those who do return often turn out to have acquired little in the way of industrial skills and are in any case, loath to enter in their home country the kinds of industries and occupations in which they worked abroad." They also contribute further to the demonstration effect which their remittances have already generated.

Thus if it is left to the free play of market forces the strategy of exporting workers is likely to have a higher cost and to yield a smaller benefit than a glance at the huge reserves of surplus labour available, the staggering figures on remittances and the apparent process of skill acquisition would suggest. In particular its impact on the productive capacity and rate of growth of the labourexporting economy (as opposed to the consumption of some groups within that economy) may be minimal or even negative, tying the economy into chronic dependance on labour export rather than laying the basis for eventual growth with full employment.

However, the stakes are too high to be rejected out of hand. There is a structured and centrally organised approach to exporting workers, pioneered by South Korea and much imitated by others including the Philippines (with the slogan, the Philippines Overseas Employment Development Board «delivers Filipino workers anywhere in the world") and even China. In the Korean version this involves construction and engineering contracts, using Korean contractors, materials, equipment and labour teams, thus maximising foreign exchange earnings in addition to workers' remittances. In the Chinese version unskilled workers are employed by Italian corporations which pay a fee direct to the chinese government which in turn pays the workers. Without going as far as this governments of most labour-exporting countries now have schemes to encourage the channelling of at least some of the foreign exchange remittances into official hands. Such schemes, if efficiently devised and implemented, can go a long way towards making exporting workers a socially profitable business - sufficiently profitable at least for it to be worth «making hay while the sun shines". But how much longer is the sun going to shine? What are the prospects for maintaining the rate of migration to the Arab region? Is there any 
change of a revival in export of workers to the industrialised economies of Western Europe? These and similar questions will be discussed in the final section of this paper.

\section{Exporting manufactured goods}

Between 1968 and 1977 the share of developing countries in world exports of manufactured goods rose from 4.5 to $7.6 \%$; in the same period their share of OECD countries imports of manufactured goods rose from 4.7 to $8.5 \%$. Particularly impressive was the performance of the "Four Little Tigers", South Korea, Taiwan, Singapore and Hong Kong, which in the same period raised their share of developing countries manufactured exports from 39.0 to $58.2 \%$, and of Brazil [from 2.4 to $6.1 \%\left({ }^{7}\right)$ ]. A highly speculative estimate of the number of jobs thus "relocated" from North to South would put it at more than $5 \mathrm{mn}$ (compared with the $6.3 \mathrm{mn}$ immigrantsworking in Western Europe in 1975).

Alongside this trend has gone the rise of a new orthodoxy in development economics, emphasising the joys of "export-led growth" and inveighing against the evils of protectionism, which violates the principle of comparative advantage and gives rise to distortions in domestic factor and product markets. "Getting factor prices rights is the central policy prescription of this school, which usually means reducing (or holding down) the price of labour, raising that of capital and reducing the price of domestic currency in terms of foreign currencies, along with a reduction in tariff rates to a low and uniform level and a removal of quatitative import restrictions (Little, Scitovsky and Scott, 1970; MacKinnon, 1974). One version of this approach specifically advocates «trade in place of migration", involving, in addition to the above, investment by previously labourimporting countries in labour-surplus economies in order to «bring work to the workers" and the opening of their markets to manufactured goods thus produced (Hiemenz and Schatz, 1979).

Labour-surplus economies are at various stages in exploring this option, pressed on them particularly by the World Bank and the International Monetary Fund. Even China is interested in learning from the experience of the Four Little Tigers and has set up four research institutes, each specialising in one of these economies.

An early step in this process of exploration is often the establishment of an export processing zone (EPZ) - a "relatively small, geographically separated area within a country, the purpose of which is to attract export-oriented industries, by offering them especially favourable investment and trade conditions as compared with the remainder of the host country (UNIDO, 1980). Such especially favourable conditions may include the duty-free import of inputs for use in export manufacturing, tax holidays, subsidisation of utilities and

(7) All figures Fröebel (1980). 
infrastructure, the absence of bureaucracy and control or subsidisation of unit labour costs. By mid-1980 there were at least fifty such zones in developing countries outside Europe, with another thirty planned or under development. Total employment in such EPZs at that time was estimated at almost one million. Among the most recently established are China's "border zones", on the coast near Hong Kong, Macao and Taiwan, with incentives for investors modelled on those offered by other Asian EPZs.

From the point of view of the labour-surplus economy, as illustrated in figure 2, capital attracted to an EPZ represents an addition to accumulation which will give employment to at least part of the surplus labour. As long as the surplus is not completed mopped up wages will not rise (from a level equivalent to between 10 and $20 \%$ of comparable Northern wages) but the increase in employment is a gain for host-economy workers. This aspect is complicated, however, by the fact that the overwhelming majority of workers in EPZs consists of young women. For instance, $85 \%$ of workers in the Mexican maquiladoras along the border with USA are women aged between 17 and 23 and the proportion in Asian EPZs is not much lower (UNIDO, 1980). This has social consequences, particularly when allied with the high rate of turnover in such jobs. It also has consequences for the extent to which EPZs mop up surplus labour rather than increase the participation rate of women, the "super-reserve army". This will vary from country to country with the extent to which women in this age range already participate in work outside the home and thus are counted as part of the labour force. EPZs are often deliberately sited to attract new entrants to the labour force rather than workers with some industrial experience.

As for foreign exchange earnings, aggregate figures look impressive. For instance, a single 200 hectare zone in Malaysia, employing 22,000, is estimated to bring in more than $\$ 470 \mathrm{mn}$ a year (Frazier, 1981). However, a high proportion of raw materials and intermediate goods are imported, the import content of the infrastructure, plant and equipment is high and, since most companies are foreign-owned, remittances from profits are high. Thus net foreign exchange earned per worker may be very little more than the (low) wage, and even this will be offset by the cost of the concessions (ever more generous as the number of competing zones increases) necessary to attract the capital. In fact, viewed purely as a source of foreign exchange, exporting workers looks more lucrative than exporting labour-intensive manufactured goods. For instance, each Bangladeshi worker abroad remits, in cash through official channels and in goods, around $\$ 900$ annually; the same worker in a EPZ $\left(^{8}\right)$ might earn around $\$ 750$, of which some $\$ 50$ might be spent on imported goods and perhaps another $\$ 100$ would go in tax and other concessions and subsidies to his employer.

However, this is to look at the question too statically. As with exporting workers, the important issue is the impact on the productive capacity and rate

(8) Hypothetical: Bangiadesh has no EPZs. 
of growth of the labour-surplus economy. This does not look particularly promising. Linkages of the EPZs with domestic economies tend to be limited and technology transfer to be confined to relatively tow-level assembly operations. As long as the labour surplus persists, this will probably remain the case. Investors' logic will only favour a move to a higher technology (and then only if adequate skills are available) once the labour surplus is exhausted (i. e., in terms of figures 1 and 2, the number of workers in the Southern subsistence Sector falls below OPs) and upward pressure begins to be exerted on the capitalist sector wage rate.

Thus for such economies as the Philippines, Bangladesh and Sri Lanka a crucial question affecting the prospects for this strategy is that of scale. Can their EPZs and other export manufacturing ventures expand to the extent that mop up their surplus labour and thus encourage a move beyond labour-only processing? The answer to this question depends in turn partly on the extent to which the Four Little Tigers, which have largely absorbed their surplus labour, can move up the technological scale and vacate space for the newer export manufacturers. These questions will be considered in the final section of this paper.

\section{Prospects}

The strategies of using surplus labour as a source of foreign exchange and as a springboard into self-sustaining development are in themselves quite problematic, as has been seen. Moreover even if internal conditions for their use by a particular surpluslabour economy are optimal (as they were in, say, South Korea fifteen years ago) the prospects of success depend also on external factors. First, how fast can the world economy and international trade be expected to grow over the next decade or so? And, secondly, what implications do expected growth rates and patterns have for the demand for immigrant labour and the location of production for the world market?

The international economic climate has, of course, already drastically deteriorated since the early 'seventies. Rates of economic growth in market economies, particularly industrialised economies, have been much lower than they were in the 'sixties.

Rates of inflation have increased and, most important for our topic, unemployment in the industrialised economies has risen to levels and rates unheard of since the 'thirties. At the same time large increases in the price of oil have unbalanced world trade and payments and generated excess demand for labour in oil-producing economies. This is the context in which growth rates in developing countries' GDP and manufactured exports have already begun to falter and in which, while migrant workers in Western Europe have been returning home, this has been more than compensated by the increase in migration to the Arab region.

This is not the place to try to characterise the crisis facing world capitalism. The main thing is to reach a view about the chances of any change in the 
gloomy trends of the past decade. Some economists are indomitably cheerful about growth prospects. Balassa, for instance, in a recent projection of demand for manufactured goods from developing countries (Balassa, 1980) has assumed an annual average growth rate in GDP in the industrial countries during the 'eighties of $3.9 \%$, a considerable increase on the rate achieved in the 'serventies. This allows him to hope that uthe Far Eastern countries that have a relatively high educational level may increasingly take the place of Japan in exporting skill-intensive products while Latin American countries may expand the exports of relatively capital-intensive products. Countries at lower stages of industrial development, in turn, may take the place of the newly-industrialising countries in exporting products that chiefly require unskilled labour» (Balassa, 1980). The authors of the 1981 World Development Report (World Bank, 1981) are less optimistic. Even on "high case» assumptions of a successful adjustment to recent increases in the price of energy and to the obsessively deflationary policies of Northern governments they project a growth rate (in GNP) in industrialised countries during the decade of $3.6 \%$; on "low case" assumptions of a less successful adjustment the projected rate is $2.8 \%$. Low-case assumptions look decidedly more realistic than hig-case. OECD members, meeting in June 1981, agreed that no recovery from the current severe recession could be expected until late 1982, by which time their unemployment would have risen to $26 \mathrm{mn}$ or $9 \%$ of their working population.

The implications for surpius-labour countries depend on what assumptions are made about the logic of relocation of production and of the use of immigrant labour and about the nature and effects of technological change. Exporting jobs and importing labour were just two of the options explored by Northern capitalists in the 'sixties and 'seventies (the others including recruitment of female labour, labour-saving technical change and job enlargement and enrichment programmes) in the face of several new developments which were working to offset the normal centralising tendencies of capitalist development (Murray, 1971). Wages were rising faster in the North than in the South, widening the already large differential; technical change was allowing the decomposition of productive processes, so that more or less unskilled workers working with modern equipment could achieve similar levels of productivity in some processes regardiess of location; labour in the North (and particularly in the USA and Britain) was becoming increasingly difficult to control - less flexible, less willing to be fitted into shiftworking, staggered-rota, fast-assemblyline and other such arrangements, less predictable, more insistent on participation in decisions and more difficult to lay off; transport and communication costs were falling; and Southern governments were going out of their way to attract foreign capital, particularly into export manufacturing, with EPZs and other concessions (Bienefeld, Godfrey and Schmitz, 1977).

Some observers emphasise minimisation of unit labour cost as the motive of capital in its search for cheap labour (Fröebel, 1980), particularly on the part of the weaker contenders in the competitive struggle between national capitals (Bienefeld, 1981). Others emphasise the problems in the control of Northern 
labour, again particularly acute in the weaker economies (Murray, 1980). On both counts slower growth in the North and the increase in unemployment there might be expected to reduce the pressures behind this search, since Northern wages might be expected to grow more slowly and labour to become more docile. However, if the dual labour market thesis is accepted (see above, page 189), the primary market may take some time to adjust to new conditions in both.these respects. And the pressure on weaker capitals to find some way of increasing their rate of profit will remain strong.

An additional complicating factor is technological change. Radical new developments in microelectronic technology are expected by many researchers to erode the comparative advantage of surplus labour economies in labourintensive manufacturing and to increase the technological gap between North and South (Hoffman and Rush, 1980: Kaplinsky, 1981). Textiles, garments and electronic and electronic goods are among industries in which micro-processorbased automation is thought to be saving labour. There is not complete agreement that this will reverse the trend towards relocation; Fröebel (1980), for instance, points out that automation economises on skills, which may continue to favour location in low-wage economies. And some of the frontrunning Newly Industrialising Countries (NICs) will certainly be in a position to make use of the new technologies. However, these technologies are also likely to displace labour in industrialised economies, particularly in informationprocessing activities and generally in labour-intensive sectors. Allied with low growth this is likely to increase pressure for protection against imports and control of immigration in the North. Even Fröebel, who questions the interpretation of automation as the inevitable "reply of the industrial countries" to relocation and suggests that there is "no discernible political force which is both willing and able to impose a drastic reduction in the international freedom of movement of commodities and capital" (Fröebel, 1980), recognises that the quantitative impact of further relocation is likely to be limited. As he puts it (p. 41), although it will grow in importance, "this process simply does not possess the potential to reduce unemployment in the developing countries in whole or in part».

In addition to the general factors affecting the search for cheap labour there are some special factors affecting international migration. In Europe the onset of the recession, reducing the demand for immigrant labour, has coincided with the "maturing" of the immigrant population, making it more difficult for employers to treat indigenous and immigrant labour as "non-competing groups" and more necessary for governments to increase provision of social infrastructure. The number of young Europeans entering the labour force has also been abnormally large. As unemployment has risen, political tensions, nurtured by right-wing organisations, have grown. During the 'seventies several European governments followed a policy of 'stabilisation', restricting new immigration, offering financial grants to those who wished to leave permanently and trying to integrate those who remained. Moreover, during the 'eighties, Greece, Portugal and Spain, all of them labour-surplus economies (with $1.3 \mathrm{mn}$ migrant 
workers in the EEC in 1976) are likely to become full members of the Community (Wedell, 1979). All these factors suggest that while intra-EEC movement of labour may continue on a limited scale, the age of massive immigration into Western Europe is over.

In the capital-surplus oil exporting countries, while the growth rate is expected to remain relatively high during the 'eighties (over $5 \%$ p. a. on Worid Bank 'low-case' assumptions) there will be several new influences on their demand for immigrant labour (World Bank, 1979.) The construction phase of their development is beginning to subside and demand for skilled workers, technicians and professionals is likely to grow in relative importance to that for unskilled and semi-skilled workers. At the same time the number of unskilled and semi-skilled nationals of oil-producing countries entering the labour market is tending to increase. The demand for unskilled and semi-skilled immigrants is still likely to increase during the decade but at a slower rate and a higher proportion is expected to come from South and South East Asian countries rather than other Arab countries. At high and middle manpower levels, however, where the bulk of the additional demand for immigrants is likely to be concentrated, the preference for Arabic speakers will still exert itself, to the detriment of the poorer Arab states. Thus for any individual labour-surplus economy the opportunities for exporting workers to the Arab region are likely to be shrinking while some can actually expect a net return flow.

FIGURE 3

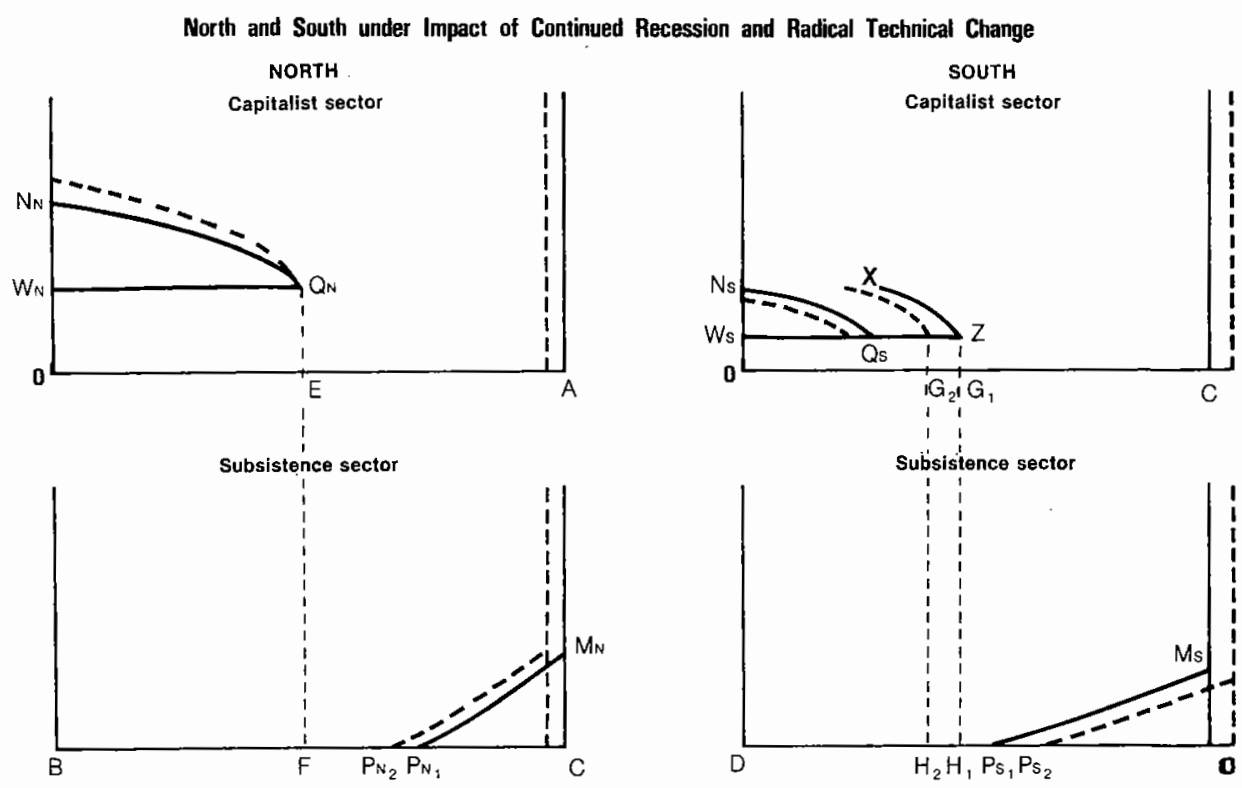

In the context of continued recession in the North and of radical technical change, then, the international labour market of the 'eighties may look something like figure 3. Growth in the Northern capitalist sector will be slow and, in spite of some re-relocation of processes from the South, relatively jobless (signified 
by the shift and change in slope of $N_{N} Q_{N}$ ). In the South, world demand for primary products will fall (signified by the inward shift of $N_{S} Q_{S}$ ) and while a few front-running NICs will 'vacate space' by moving higher up the technological scale this will result in only limited opportunities for labour-surplus economies (how limited depending on the impact of labour-saving technical change on location of production). At the same time there will be a net return flow of migrants from North to South, less than offset by continued migration (at a lower rate) to the Arab region (signified by the shifts in the axes and the $M_{N} P_{N}$ and MsPs curves). As a consequence the size of the labour surplus in the South will increase (from $\mathrm{Ps}_{1} \mathrm{H}_{1}$ to $\mathrm{PS}_{2} \mathrm{H}_{2}$ in terms of figure 3 ) while a high rate of unemployment persists in the North. To an extent, having developed a sizeable reserve army of its own Northern capital will have less need of an international reserve army.

If this gloomy prospect has any grains of truth in it, integration into the international labour market in either of these ways does not look a particularly promising strategy for most labour-surplus economies. Indeed it is possible that many of them, World Bank and IMF advice notwithstanding, may be driven by their balance-of-payments problems towards closing rather than opening their economies. In which case the time may be ripe for a revival of the surplus labour analyses of the 'fifties and 'sixties - the Nurksean hidden saving potential, the Lewis model, etc. - and of the schemes for regional integration and political reorganisation which alone can make this approach feasible for the smaller economies.

\section{BIBLIOGRAPHY}

AMIN, Samir, 1974 - Modern Migrations in Western Africa, OUP, Oxford.

AMIN, Samir, 1978 - Unequal Development, Harvester, Hassocks.

BALASSA, Bela, 1980 - «The process of industrial development and alternative development strategies", World Bank Staff Working Paper no. 438, October.

BIENEFELD, Mandred - Forthcoming, chapter in Manfred Bienefeld and Martin Godfrey, (ed), The Struggle for Development, John Wiley, Chichester.

BIENEFELD, Manfred and Martin Godfrey, 1978 - "Surplus labour and underdevelopment», IDS Discussion Paper no. 138.

BIENEFELD, Manfred, Martin Godfrey and Huber Schmitz, 1977 - «Trade unions and the 'New' internationalisation of Production', Development and Change, vol. 8, no. 4.

BIRKS, J. S. and C. Sinclair, 1979 - International Migration and Development in the Arab Region, ILO, Geneva.

BÖHNING, W. R., 1972 - The Migration of Workers in the United Kingdom and the European Community, OUP, Oxford.

BÖHNING, W. R., 1979 - "International migration in Western Europe: Reflections on the past five years", International Labour Review, 118.4, July-August.

CARDOSO, Fernando Henrique, 1972 - "Comentário sobre os conceitos de superpopulação relativa e marginalidaden, cap. VII in O Modelo Político Brasileiro e Outros Ensaios, Difusão Europeia do Livro, São Paulo.

ECEVIT, Z. and K. C. Zachariah, 1978 - International Labour Migration, Finance and Development, 15.4, December. 
EMMANUEL, Arghiri, 1972 - Unequal Exchange: a Study in the Imperialism of Trade, MRP, New York.

FRAZIER, Mark, 1981 - «Free trade zones: a growing phenomenon around the globe", Transatlantic Perspectives, no. 4, January.

FRÖBEL, Folker, $1980--$ The Current Development of the World Economy, Mimeo, April.

GODFREY, Martin, 1979 -- «Rural-urban migration in a 'Lewis Model' Context", The Manchester School, no. 3, September.

HIEMENZ, U. and K. W. Schatz, 1979 - Trade in Place of Migration, ILO, Geneva.

HOFFMAN, K. and H. Rush, 1980 - Microelectronics, Industry and the Third World, Mimeo, SPRU, University of Sussex, UK.

International Labour Office, 1972 - Employment, Incomes and Equality: a Strategy for Increasing Productive Employment in Kenya, Geneva.

KAPLINSKY, R., 1981 - «Radical technical change and manufactured-export growth strategies", Vierteljahresberichte der Entwicklungs/anderforschung, March.

LEWIS, W. A., 1954 - «Economic development with unlimited supplies of labour», The Manchester School, vol. 26, May.

MAHMOOD, Raisul Awal, 1981 - Migrants' Remittances as a Source of Foreign Exchange - The Experience of Bangladesh, Mimeo, IDS, Sussex.

MARX, Karl, 1867 (1954 edition) - Capital, vol. 1, Lawrence and Wishart, London.

MURRAY, R., 1972 - "Underdevelopment, international firms and the international division of labour", Towards a New World Economy, Rotterdam, University Press.

MURRAY, Robin, 1980 - Imperialism and the Labour Process, Mimeo, IDS, Sussex.

NUN, J., 1969 - "Superpoblacion relativa, ejercito industrial de reserva y mass a marginal», $R e-$ vista Latinoamericana de Sociologia, vol. 5, no. 2.

NURKSE, Ragnar, 1953 - Problems of Capital Formation in Underdeveloped Countries, Basil Blackwell, Oxford

PAINE, Suzanne, 1974 - Exporting Workers: The Turkish Case, CUP, London.

PIORE, M. J., 1971 - "The dual labour market: theory and implications", in D. M. Gordon, Readings in Political Economy: an Urban Perspective.

PIORE, M. J., 1979 - "Birds of passage», Migrant Labour and Industrial Societies, CUP.

PREBISCH, Raul, 1959 - "Commercial policy in underdeveloped countries", American Economic Review, Papers and Proceedings, 49.2

QUIJANO OBREGON, Anibal, 1974 - "The marginal role of the economy and the marginalised labour force», Economy and Society, vol. 3, no. 4, November.

RANIS, G. and J. C. H. Fei, 1961 - "A theory of economic development", American Economic Review, September.

SINGER, Hans, 1950 - "The distribution of gains between investing and borrowing countries", American Economic Review, Papers and Proceedings, 11.2, May.

UNIDO, 1980 - Working Papers on Structural Changes no. 19, "Export processing zones in developing countries".

WARREN, Bill, 1973 - «Imperialism and capitalist industrialisation". New Left Review, SeptemberOctober.

WARREN, Bill, 1980 - Imperialism: Pioneer of Capitalism, Verso Paperback, London,

WEDELL, George, 1979 - "The enlargement of the european community: implications for employment and free movement of workers", Manchester Business School and Centre for Business Research, Working Paper 38.

WORLD Bank, 1979 - Research Project on Labour Migration and Manpower in the Middle East and North Africa, Interim Report, Washington, December.

WORLD Bank, 1981 - World Development Report, Washington. 